\title{
UDC 378.147.091.33-027.22
}

\section{PLATFORMA MULTIMEDIALNA JAKO NARZĘDZIE WSPIERAJĄCE NAUCZANIE JEZZYKA POLSKIEGO}

\author{
Malgorzata Kulakowska \\ Dr n. hum. Dyrektor Centrum Polonijnego UR \\ Uniwersytet Rzeszowski, Rzeszów, Polska \\ ORCID ID 0000-0002-8202-0667 \\ mkulakowska@ur.edu.pl
}

\begin{abstract}
Streszczenie. Artykuł przedstawia platformę multimedialną do nauki języka polskiego jako obcego na poziomie B1. Platforma jest narzędziem przeznaczonym dla ukraińskojęzycznych studentów, którzy znają już język polski na poziomie średniozaawansowanym. Osoby korzystające z platformy znajdą na niej materiały do ćwiczenia wszystkich sprawności językowych. Platforma zawiera odpowiednio dobrane ćwiczenia w języku polskim. Platforma powstała w ramach projektu „Język polski-blisko, coraz bliżej”, który jest realizowany i finansowany w ramach Programu NAWA „Promocja języka polskiego” W artykule są omówione części składowe platformy, ich przeznaczenie oraz możliwości komunikacyjne. Ponadto w części wstępnej przedstawiony został przegląd podobnych narzędzi do nauki języka polskiego. W części wstępnej została także omówiona rola TIK (technologii informacyjno-komunikacyjnej) w nauczaniu języka polskiego jako obcego.
\end{abstract}

Stowa kluczowe: platforma multimedialna; nauka języka polskiego jako obcego $\mathrm{z}$ wykorzystaniem TIK.

Ogólne przedstawienie problemu. W związku pandemią Covid 19 i wynikającą $\mathrm{z}$ tego $\mathrm{z}$ koniecznością zdalnego nauczania wzrosła rola wszelkiego rodzaju narzędzi wspierających to nauczanie. Narzędzia określamy skrótem TIK, który oznacza rodzinę technologii przetwarzających, gromadzących i przesyłających informacje w formie elektronicznej. Zamiennie możemy stosować nazwę technologii teleinformatycznych lub technik informacyjnych. Jest to pojęcie z pogranicza nauki, techniki i społeczeństwa informacyjnego (Basińska 2017).

Jednym $\mathrm{z}$ takich narzędzi jest platforma multimedialna, nazywana także platformą edukacyjną. Przez to pojęcie należy rozumieć system komputerowy pozwalający organizować i wspomagać nauczanie przez Internet. Podstawowe zadanie platformy to gromadzenie materiałów dydaktycznych oraz organizowanie i udostępnianie ich odbiorcom za pośrednictwem sieci. Zalety platformy jako medium służącego do nauki to:

1. Możliwość zgromadzenia w jednym miejscu zasobów edukacyjnych ćwiczeń, tekstów, quizów itp.

2. Brak ograniczeń w czasie i przestrzeni - uczeń i nauczyciel mogą korzystać z zasobów zgromadzonych na platformie w dowolnym czasie i miejscu - jedynym warunkiem jest dostęp do Internetu. 
3. Platforma jest interaktywna - dzięki czatom, a także możliwości wstawiania komentarzy w blogach pozwala na komunikację nauczyciela i ucznia. Jednak przy zastosowaniu platformy jako uzupełnienia tradycyjnej kontaktowej formy nauki główna komunikacja odbywa się podczas zajęć, a rolę zdalnego narzędzia komunikacji częściej przejmuje poczta elektroniczna.

Autorzy Wrocławskiego Portalu Informatycznego (http://informatyka.wroc.pl/kursy/) wyróżniają cztery sposoby wykorzystania platform edukacyjnych. Mogą one być:

1. Wsparciem dla tradycyjnych kursów.

2. Hybrydową formą nauki z przewagą tradycyjnego kursu.

3. Hybrydową formą nauki z przewagą nauczania zdalnego.

4. Miejscem, gdzie są przeprowadzane kursy w całości zdalne.

Omawiana w artykule platforma „Język polski - blisko, coraz bliżej” jest przeznaczona do wykorzystywania jako wsparcie dla tradycyjnych kursów.

Analizowanie najnowszych badań i publikacji. W Internecie działa wiele platform do nauki języka polskiego jako obcego. Można tu wymienić strony płatne: np. https://e-polish.eu/polski-dla-obcokrajowcow, rozbudowaną płatną platformę do nauki i nauczania języka polskiego. Platforma ta jest prowadzona przez szkołę języków obcych Glossa w Krakowie. Bezpłatne platformy to np. http://www.popolskupopolsce.edu.pl/ - platforma przeznaczona do nauki języka polskiego dla początkujących. Dla początkujących jest także przeznaczona platforma https://polski.info/pl. Materiały umieszczane na platformach często są uzupełnieniem do wydawanych podręczników, np. podręcznik Studiologia ma swoją stronę https://www.studiologia.edu.pl/, na której są umieszczone interaktywne ćwiczenia z zakresu proponowanej przez podręcznik tematyki.

Ocena TiK w procesie nauczania języków obcych pojawia się z reguły w publikacjach dotyczących dydaktyki języka angielskiego. Anna Basińska (2017) zauważa, że zgodnie z zaleceniem Parlamentu Europejskiego i Rady Europejskiej z dnia 18 grudnia 2006 roku w sprawie kompetencji kluczowych w procesie uczenia się przez całe życie, określono 8 kluczowych kompetencji w uczeniu się przez całe życie (...) należy do nich także porozumiewanie się w językach obcych. Włączanie nowoczesnych technologii informacyjno-komunikacyjnych w proces edukacyjny sprzyja rozwojowi tej kompetencji, ponieważ aktywności w sieci nie uruchamia zadanie z podręcznika tylko naturalna sytuacja, np. nagranie $\mathrm{z}$ autentycznego kanału $\mathrm{w}$ serwisie Youtube.

Badania ankietowe prowadzone przez Beatę Gałan (2020) wśród użytkowników platform edukacyjnych wykazały, że optymalnym rozwiązaniem, opartym na połączeniu zalet pracy kontaktowej i zdalnej, może być wykorzystanie metody 
hybrydowej, polegającej na uzupełnieniu zajęć odbywających się w klasie aktywnościami przygotowanymi na platformie e-learningowej. Przeprowadzone badania pokazały również, że pomimo intensywnej aktywności w sieci, jaką wykazują się studenci, ich postawa w stosunku do kształcenia językowego odbywającego się w całości na odległość pozostaje dość sceptyczna.

Umieszczenie celów artykułu (zadań). Celem artykułu jest prezentacja platformy do nauki języka polskiego „Język polski- blisko, coraz bliżej”, czyli przedstawienie głównych założeń projektu finansowanego ze środków NAWA w ramach programu „Promocja języka polskiego”, w ramach którego ta platforma została stworzona.

Wyniki badania. Celem projektu PJP/PJP/2020/1/00019 było stworzenie platformy e-learningowej "Język polski- blisko, coraz bliżej" zwierającej ćwiczenia z języka polskiego dla cudzoziemców odnoszące się do wszystkich sprawności, a także informacje z zakresu historii i kultury polskiej i blog z wpisami lektorów. Platforma ta jest też medium ułatwiającym kontakt osób uczących się języka polskiego z lektorami, poprzez forum słuchacza i zawarty tam moduł ,słowo tygodnia”. Wszystkie treści zamieszczone na platformie są dostosowane do poziomu biegłości językowej adresatów Platformy, który został określony jako B1 wg ESOKJ.

Narzędzie to jest adresowane przede wszystkim do ukraińskojęzycznego odbiorcy, uwzględnia jego specyficzne potrzeby. Ponadto celem platformy jest promowanie języka i kultury polskiej wśród użytkowników. Dobór treści programowych poprzedzały badania ankietowe wśród studentów ukraińskojęzycznych studiujących na Uniwersytecie Rzeszowskim i na Uniwersytecie im. Ogijenki w Kamieńcu Podolskim (który jest partnerem w projekcie). Studenci oceniali poziom trudności oraz atrakcyjność prezentowanych zadań. Zadania te są skorelowane $\mathrm{z}$ podręcznikiem o tym samym tytule, który także ma być realizowany w ramach w/ w projektu. Kolejną fazą było ostateczne zredagowanie i przygotowanie ćwiczeń interaktywnych przy użyciu ogólnodostępnego narzędzia internetowego learningapps oraz formularzy google.

Ćwiczenia są powiązane z rozdziałami podręcznika „Język polski - blisko, coraz bliżej" będą rozwijały słownictwo w następujących kategoriach: święta w Polsce i Ukrainie, dane osobowe, wygląd zewnętrzny, rodzina, zdrowie i sport, mieszkanie dla studenta, edukacja i studiowanie, prawo i przekroczenia prawa, sprawy młodych ludzi, podróżowanie, poszukiwanie pracy, klimat w Polsce, zakupy, świat mediów i wyrażanie emocji. Taki dobór tematyki został ustalony podczas spotkania lektorów i skonsultowany ze studentami obu uczelni, dzięki temu materiał leksykalny uwzględnia nie tylko profil językowy słuchacza, ale również specyfikę wiekową i kulturową grupy 
docelowej. Potrzeby studentów różnią się od potrzeb dorosłych odbiorców. Ponadto zostały przygotowane materiały dotyczące postaci Polaków związanych z Ukrainą.

Materiały te zostały przygotowane przez zespół doświadczonych lektorów języka polskiego pracujących w obu uczelniach. Na platformie zaprojektowano także miejsce dla lektorów języka polskiego. Dzięki zamieszczeniu w części dla lektorów „bloga lektora” platforma będzie służyć podnoszeniu kompetencji dydaktycznych lektorów języka polskiego.

Platforma jako sposób prezentowania treści dydaktycznych jest innowacyjnym rozwiązaniem, ponadto zakładamy jej interaktywność - zarówno w postaci interaktywnych testów i ćwiczeń, jak i w postaci forum słuchacza i bloga lektorskiego. Taki sposób prezentacji treści jest innowacyjny ze względu na spełnienie wymagań nauczania multisensorycznego. Na platformie zamierzamy także umieszczać aktualne informacje dotyczące życia naukowego i kulturalnego w Rzeszowie i Kamieńcu Podolskim, działań naukowych i dydaktycznych związanych z promocją języka polskiego w obu jednostkach.

Platforma będzie zatem narzędziem promocji języka polskiego. Jednym z jej zadań jest zainteresowanie odbiorcy pogłębieniem znajomości języka i kultury polskiej. Dlatego język tekstów umieszczanych na platformie będzie przystępny dla osób uczących się dopiero języka polskiego

Wskazanie grup docelowych. Pierwszym kręgiem adresatów są ukraińskojęzyczni studenci. Będą oni przede wszystkim odbiorcami podręcznika. Stanowią oni zróżnicowaną, ale dającą się opisać grupę docelową. W grupie tej są młodzi ludzie studiujący na Ukrainie polonistykę i inne kierunki, którzy widzą szansę na rozwój kariery zawodowej w opanowaniu języka polskiego. Język polski jest dla nich przepustką do uzyskania możliwości rozwoju zarówno w kraju zamieszkania jak i za granicą (w Polsce). Do grupy docelowej odbiorców należą także absolwenci szkół średnich na Ukrainie, którzy wybrali studia na różnych uczelniach w Polsce. Język polski będzie dla nich podczas studiów w Polsce językiem codziennej komunikacji w różnych sytuacjach oficjalnych i nieoficjalnych. Wśród studentów z Ukrainy zarówno podejmujących studia w Polsce, jak i uczących się języka polskiego w kraju zamieszkania jest znaczna grupa osób, które mają polskie pochodzenie.

Znajomość języka polskiego w tej grupie jest zróżnicowana, jednak można wskazać dodatkową motywację do nauki polskiego - jest nią chęć poznania języka polskiego jako języka narodowego. Rozeznanie potrzeb grup docelowych, czyli pokazanie języka polskiego jako języka, który stwarza możliwości rozwoju zawodowego, języka, który umożliwia studia w atrakcyjnym edukacyjnie kraju oraz języka Polaków na Ukrainie, stwarza możliwości odpowiedniego doboru treści podręcznika i związanych z nim tematycznie ćwiczeń zamieszczanych na platformie. 
Znacznie szerszą grupę docelową stanowią odbiorcy platformy multimedialnej. Oprócz opisanych powyżej grup, do których potrzeb treści zawarte w podręczniku i na platformie są odpowiednio dostosowane, wśród odbiorców Platformy można wskazać nauczycieli języka polskiego w Polsce i za granicą.

Platforma jest adresowana do lektorów uczących języka polskiego studentów ukraińskich, ale zamieszczony na niej blog będzie otwarty dla wszystkich nauczycieli, którzy będą chcieli się dzielić swoimi doświadczeniami na temat nauki języka polskiego jako obcego. Podobnie jest $\mathrm{z}$ treściami zamieszczanymi na forum słuchacza, które także będzie otwarte dla wszystkich uczących się języka polskiego jako obcego. Dopuszczamy dowolność tematyczną - zamierzamy stworzyć kilka działów forum. Jednym z nich jest podforum „słowo tygodnia”. W tym miejscu staramy się jako moderatorzy zainspirować słuchaczy do rozszerzenia wiedzy na temat znaczeń poszczególnych słów ich konotacji, łączliwości, zasad odmiany itp.

Dzięki zamieszczanym informacjom na temat wydarzeń kulturalnych i naukowych w siedzibach Wnioskodawcy i Partnera, a także w wydarzeniach organizowanych przez NAWA, Platforma będzie też skierowana do osób obcojęzycznych zainteresowanych wydarzeniami kulturalnymi i naukowymi (popularyzującymi naukę i wymianę studencką) organizowanymi w Rzeszowie oraz przez NAWA oraz do mieszkańców Kamieńca Podolskiego i okolic zainteresowanych wydarzeniami kulturalnymi i naukowymi (popularyzującymi naukę i wymianę studencką) związanymi z promocją języka i kultury polskiej.

Dzięki treściom (dostosowanym do potrzeb studentów) zawartym w podręczniku i na Platformie studenci będą mogli poznać realia życia ich polskich rówieśników, język i mentalność. Będą także mogli zapoznać się z informacjami na temat Polski i jej kultury. Będą też na bieżąco informowani o wydarzeniach związanych $\mathrm{z}$ promocją języka polskiego, o wydarzeniach kulturalnych oraz promujących naukę w Rzeszowie i w Kamieńcu Podolskim.

Tak przygotowane produkty projektu będą promowały NAWA oraz Wnioskodawcę i Partnera jako instytucje dbające o poziom nauczania języka polskiego jako obcego, dbające o jego prestiż oraz promujące kulturę polską.

Dzięki forum słuchacza będą mogli podzielić się swoimi spostrzeżeniami na temat nauki języka polskiego jako obcego, co przyczyni się do dalszego podnoszenia jakości nauczania. Natomiast blog lektora wpłynie na jakość nauczania języka polskiego, będzie też podnosił kompetencje lektorów języka polskiego. Studenci będą mieli też możliwość poznania najważniejszych informacji o Polsce i jej kulturze.

Wnioski $z$ tych badań i perspektywy dalszych studiów $w$ tym kierunku. Zakładamy, że tak przygotowana platforma będzie stale wzbogacanym narzędziem do 
nauki języka polskiego jako obcego. Dzięki temu, że można z niej korzystać w każdym miejscu i czasie stanowi dobre źródło dla zagranicznych studentów, którzy często uczą się języka polskiego, mając ograniczony dostęp do tradycyjnych pomocy dydaktycznych takich jak podręczniki, zeszyty ćwiczeń itp. Dzięki takim komponentom jak Forum słuchacza Platforma „Język polski- blisko, coraz bliżej” umożliwi komunikację lektorów ze słuchaczami, poznanie ich potrzeb i dostosowanie do nich tradycyjnych zajęć.

\title{
WYKAZ UŻYWANYCHŹRÓDEL
}

1. Platformy edukacyjne. Wrocławski Portal Informatyczny. (n. d.). Retrieved from http://informatyka.wroc.pl/kursy/mod/page/view.php?id=157\#licencjaGPL

2. Basińska, A. (2017). Teoria w pigutce. Warszawa.

3. Gałan, B. (2020). Nauka języka obcego na odległość. Potencjał a skuteczność. E-mentor: Nauka języka obcego na odległość. Potencjał a skuteczność.

\section{MULTIMEDIA PLATFORM AS A TOOL FOR SUPPORTING TEACHING POLISH}

\author{
Małgorzata Kulakowska \\ Dr n. hum. Dyrektor Centrum Polonijnego UR \\ Uniwersytet Rzeszowski, Rzeszów, Polska \\ ORCID ID 0000-0002-8202-0667 \\ mkulakowska@ur.edu.pl
}

\begin{abstract}
The article presents a multimedia platform for learning Polish as a foreign language at B1 level. The platform is a tool intended for Ukrainian-speaking students who already know Polish at an intermediate level. People using the platform will find there materials to practice all language skills. These types of multimedia tools for learning a foreign language allow you to gather various teaching materials in one place on the Internet, which makes them available to course participants, pupils and students at any time and place. Some language learning platforms also have the advantage of being interactive.

The materials collected on the platforms allow for a different scope of use - they can be a support during a traditional course, they can be an element of hybrid learning or be a medium on which the entire course is posted. The resources of the Polish network include various multimedia platforms for learning Polish - the following websites are listed here: e-polish, popolskupopolsce.pl, polski.info.pl and studiologia.pl

The article describes the Platform "Polish language - close, ever closer". It contains exercises in Polish that are properly selected to meet the needs of the recipients. The platform was created as part of the project "Polish language - close, ever closer", which is implemented and financed under the NAWA Program "Promotion of the Polish language". The article discusses the components of the platform, their purpose and communication possibilities. In addition, the introductory part presents an overview of similar tools for learning Polish. The introductory part also discusses the role of ICT (information and communication technology) in teaching Polish as a foreign language.
\end{abstract}

Key words: multimedia platform; learning Polish as a foreign language with the use of ICT. 


\section{KUŁAKOWSKA}

Platforma multimedialna jako narzędzie wspierające nauczanie języka polskiego

\section{REFERENCES}

1. Platformy edukacyjne. Wrocławski Portal Informatyczny. (n. d.). Retrieved from http://informatyka.wroc.pl/kursy/mod/page/view.php?id=157\#licencjaGPL

2. Basińska, A. (2017). Teoria w pigutce. Warszawa.

3. Gałan, B. (2020). Nauka jezzyka obcego na odległość. Potencjał a skuteczność. E-mentor: Nauka języka obcego na odległość. Potencjał a skuteczność.

Матеріали надійшли до редакції 15.09.2021 р. 